\title{
The SNM Practice Guideline on Breast Scintigraphy
}

$\mathbf{T}$ his month's issue of Journal of Nuclear Medicine Technology includes the SNM Practice Guideline for Breast Scintigraphy with BreastSpecific $\gamma$-Cameras 1.0 (1). This guideline concisely summarizes the clinical indications for the type of radionuclide breast imaging known as scintimammography, reflecting the current assessment of this technology by an SNM guideline committee assembled for this purpose. The guideline was approved in June 2010 by the board of directors of the SNM after almost 2 years of review of the previous SNM guideline for scintimammography as well as deliberations and publications by the American College of Radiology Appropriateness Criteria Panel on Breast Imaging, the American College of Surgeons Consensus Conference III, and the Institute for Clinical Systems Improvement.

The guideline appears approximately 38 years after a publication entitled "99mTc-Pertechnetate Scintigraphy as an Aid in the Diagnosis of Breast Masses," which described the initial use of a $\gamma$-camera and a ${ }^{99 \mathrm{~m}} \mathrm{Tc}$ radiopharmaceutical to identify and to assist in the differential diagnosis of breast masses either palpated or detected by mammography but with a degree of uncertainty about the potential malignant nature of the mass (2). The basis for localization of the tracer was never clearly defined, but it is likely that ${ }^{99 m}$ Tc-pertechnetate scintimammography represented simply "tumor stain" in the increased extracellular fluid space of a solid mass surrounded by adipose

Received Oct. 19, 2010; revision accepted Oct. 26, 2010.

For correspondence or reprints contact: Stanley J. Goldsmith, Division of Nuclear Medicine, Department of Radiology, New York-Presbyterian Hospital/Weill Cornell Medical Center, 525 E. 68th

St., Starr-221, New York, NY 10021.

E-mail: sjg2002@med.cornell.edu

COPYRIGHT ( ) 2010 by the Society of Nuclear Medicine, Inc.

DOI: 10.2967/jnumed.110.084400

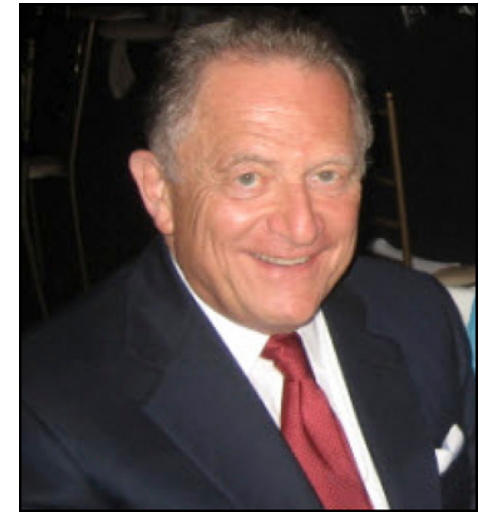

tissue. Subsequently, the technique was pitted against mammography as a screening agent, which was not the original intention. Not surprisingly, ${ }^{99 \mathrm{~m} T c-}$ pertechnetate scintimammography was found to be less effective than mammography as a diagnostic tool and fell into disuse. In the 1990s, Tiling et al. reawakened interest in scintimammography using ${ }^{99 \mathrm{~m}} \mathrm{Tc}$-sestamibi as the diagnostic tracer (3). This radiotracer is lipid-soluble and in the intracellular environment binds to mitochondrial proteins. In the setting of a solid breast mass, and malignant tissue in particular, these features favor localization and therefore improve image quality. Piccolo et al. used a ${ }^{99 \mathrm{~m}} \mathrm{Tc}$-diphosphonate compound with a similar image acquisition technique and obtained favorable results (4). Localization was likely a reflection of a small molecule retained in the extracellular fluid space augmented by binding to microcalcifications.

Regardless of the ${ }^{99 \mathrm{~m}} \mathrm{Tc}$ tracer used, breast image acquisition utilized a standard $\gamma$-camera. The best images were obtained in the lateral position with the breast dependant and as far from the thorax as possible since there was a considerable amount of radiotracer throughout the body. The substantial shielding in a traditional $\gamma$-camera resulted in masking several centimeters of breast tissue, and the bulky camera head made acquisition of other projections difficult.
The present guideline recognizes use of breast-specific $\gamma$-imaging that applies a small-field-of-view camera dedicated to low-energy $\gamma$-signal acquisition. This instrument has thinner shielding enabling acquisition of a greater area of breast tissue. In addition, the technique encourages, and the smaller camera head makes possible, acquisition of images simulating $\mathrm{x}$-ray mammography: cephalocaudal, lateromedial, and mediolateral images. Thus, the breast-specific $\gamma$-camera makes possible the acquisition of images with positions comparable to mammography. There are multiple references to the excellent clinical results obtained with this technologic advance (5-9).

The guideline recognizes that other imaging modalities such as breast ultrasound and MRI may be useful in the assessment of breast masses and of women with concerns about breast malignancy who are not satisfied by traditional imaging techniques. The guideline also recognizes that other ${ }^{99 \mathrm{~m}} \mathrm{Tc}$ radiopharmaceuticals such as 99m Tc-tetrofosmin may be preferred by some physicians. Finally, the guideline draws attention to the recent development of the potential use of $\gamma$-probes as an aid in needle localization and biopsy.

Breast imaging has been and will likely remain a controversial diagnostic radiologic procedure. MRI is a sensitive but not specific tool to resolve areas of uncertainty. Scintimammography can provide additional information in uncertain cases, in women with dense breasts or breast prostheses in whom traditional mammography is often inadequate, and when there is a need to identify additional sites for further evaluation.

\section{Stanley J. Goldsmith}

New York-Presbyterian Hospital/Weill Cornell Medical Center

New York, New York 


\section{REFERENCES}

1. Goldsmith SJ, Parsons W, Guiberteau MJ, et al. SNM practice guideline for breast scintigraphy with breastspecific $\gamma$-cameras 1.0. J Nucl Med Technol. 2010;38:219-224.

2. Cancroft ET, Goldsmith SJ. ${ }^{99 \mathrm{~m}} \mathrm{Tc}$-pertechnetate scintigraphy as an aid in the diagnosis of breast masses. Radiology. 1973;106:441-444.

3. Tiling R, Khalkhali I, Sommer $\mathrm{H}$, et al. Role of technetium-99m sestamibi scintimammography and contrast-enhanced magnetic resonance imaging for the evaluation of indeterminate mammograms. Eur J Nucl Med. 1997;24:1221-1229.
4. Piccolo S, Lastoria S, Mainolfi C, Muto P, Bazzicalupo L, Salvatore M. Technetium-99mmethylene diphosphonate scintimammography to image primary breast cancer. J Nucl Med. 1995; 36:718-724.

5. Coover LR, Caravaglia Kuhn P. Scintimammography with dedicated breast camera detects and localizes occult carcinoma. $\mathrm{J} \mathrm{Nucl}$ Med. 2004;45:553-558.

6. Brem R, Rapelyea J, Zisman G, et al. Occult breast cancer: scintimammography with high-resolution breast-specific gamma camera in women at high risk for breast cancer. Radiology. 2005;237:274 280.
7. Brem R, Fishman M, Rapelyea J. Detection of ductal carcinoma in situ with mammography, breast specific gamma imaging, and magnetic resonance imaging: a comparative study. Acad Radiol. 2007;14:945-950.

8. Brem R, Petrovice I, Rapelyea J, et al. Breastspecific gamma imaging with ${ }^{99 \mathrm{~m} T c}$-sestamibi and magnetic resonance imaging in the diagnosis of breast cancer: a comparative study. Breast J. 2007;13:465-469.

9. Brem R, Floerke A, Rapelyea J, Teal C, Kelly T, Mathur V. Breast-specific gamma imaging as an adjunct imaging modality for the diagnosis of breast cancer. Radiology. 2008;247:651-657. 